Original Research Article

\title{
Impact of oral palonosetron in improving quality of life as compared to other oral 5-HT3 antagonists in delayed chemotherapy induced nausea and vomiting in patients of head and neck cancer
}

\author{
Anubhuti Khare ${ }^{1}$, Varsha Mandloi ${ }^{2}$, Abhishek Shrivastava ${ }^{3 *}$, Arun Kumar Shrivastava ${ }^{4}$, \\ Prashant Wadagbalkar ${ }^{1}$, Akhilesh Kumar ${ }^{1}$
}

${ }^{1}$ Department of Pharmacology, ABVGMC Vidisha, Madhya

Pradesh, India

${ }^{2}$ Department of Radiation Oncology, GMC, Bhopal,

Madhya Pradesh, India

${ }^{3}$ Department of Radiation

Oncology, ABVGMC, Vidisha,

Madhya Pradesh, India

${ }^{4}$ Department of Pharmacology, GMC, Bhopal, Madhya Pradesh, India

Received: 07 December 2018

Revised: 02 February 2019

Accepted: 11 February 2019

*Correspondence to:

Dr. Abhishek Shrivastava, Email: aadityaonco1527@ gmail.com

Copyright: (C) the author(s), publisher and licensee Medip Academy. This is an openaccess article distributed under the terms of the Creative Commons Attribution NonCommercial License, which permits unrestricted noncommercial use, distribution, and reproduction in any medium, provided the original work is properly cited.

\begin{abstract}
Background: Chemotherapy induced nausea and vomiting (CINV) remains one of the most common and debilitating complications of highly emetogenic chemotherapy (HEC). This study was undertaken to evaluate palanosetron against other 5-HT3 receptor antagonists in preventing delayed CINV with the aim of achieving complete response (CR) and improving quality of life (QoL).

Methods: This was a prospective, observational study conducted on 75 histopathologically proven patients of squamous cell carcinoma of Head and Neck (H\&N), who came to the Department of Radiation Oncology, Gandhi Medical College and Hamidia Hospital, Bhopal from January to December 2015. Standard protocol based chemotherapy containing highly emetogenic cisplatin based chemotherapy was administered to all the patients. For prevention of delayed chemotherapy induced nausea and vomiting all patients were prescribed oral 5-HT3 antagonists. Oral Ondansetron 4mg TDS was given to cohort 1, oral Granisetron $1 \mathrm{mg}$ BD to cohort 2 and oral Palanosetron $0.5 \mathrm{mg}$ OD was given to cohort 3 . They were graded as complete response when they did not have complains of nausea and vomiting.

Results: In Ondansetron, Granisetron and in Palanosetron cohort 29\%, 53\% and 98\% patients had complete response.

Conclusions: Palanosetron appears superior. Our study was conducted on handfull of patients and compared palanosetron against only two 5-HT3 receptor antagonists, so a larger study is suggested to establish the efficacy and better response of palanosetron.
\end{abstract}

Keywords: Delayed CINV, Complete response, Head and neck cancer, Quality of life

\section{INTRODUCTION}

Despite significant progress in its management, chemotherapy-induced nausea and vomiting (CINV) remains one of the most common and debilitating complications of highly emetogenic chemotherapy
(HEC). ${ }^{1}$ Nausea and vomiting has been classified as acute, delayed, anticipatory, breakthrough, refractory, and chronic. Acute nausea and vomiting is the nausea \&vomiting experienced during the first 24 hours after chemotherapy administration. Delayed CINV occurs after the acute phase that peaks in 2-3 days and can last upto 1 week. ${ }^{2}$ Chemotherapy damages the gastrointestinal 
mucosa, causing the release of serotonin (5hydroxytryptamine 5-HT) from enterochromaffin cells in the small intestine, which, in turn, activates 5-HT3 receptors located on vagal afferents. Activated vagal afferent fibres send signals to the brain stem vomiting centres, initiating emesis. ${ }^{3}$ As 5-HT3 receptors play a key role in pathophysiology of CINV, 5-HT3 receptor antagonists have been used for prevention of the same. Various pharmacological agents used are ondansetron, granisetron, dolasetron and palonosetron. Palonosetron is highly selective and has high affinity for 5hydroxytryptamine (5-HT3) receptors. It has a substantially longer plasma half-life $(\sim 40 \mathrm{~h})$ than the other 5-HT3 receptor antagonists $(\sim 10 \mathrm{~h})$. It is proposed that palonosetron exhibits allosteric binding and positive cooperativity, and that this in turn triggers a receptor internalization of 5-HT3 receptors resulting in a longlived inhibition of receptor function. ${ }^{4}$

Thus, this study was undertaken to evaluate palonosetron against other 5-HT3 receptor antagonists in preventing delayed chemotherapy induced nausea and vomiting (CINV) with the aim of achieving complete response (CR) and improving quality of life (QOL).

\section{METHODS}

This was a prospective, observational study which was conducted on 75 histopathologically proven patients of squamous cell carcinoma of Head and Neck $(\mathrm{H} \& \mathrm{~N})$, who came to the Department of Radiation Oncology, Gandhi Medical College and Hamidia Hospital, Bhopal, during a 12 months period from January to December 2015. Patients were previously untreated.

For this study the patients were selected based on the inclusion criteria.

\section{Inclusion criteria}

- $\quad$ Patients with age less than 70 years

- Both sexes

- Histologically proven cases of squamous cell carcinoma

- Karnofsky performance score/scale more than or equal to 70

- Normal haematological, renal

- Liver function tests

- $\quad$ Normal chest X-ray

Patients with history of allergy to 5HT-3 antagonists, any associated medical condition causing nausea/vomiting, age more than 70 years, history of prior irradiation or surgery and histology other than squamous cell carcinoma were excluded.

These patients were divided into three cohorts each cohort comprising 25 patients.
Standard protocol based chemotherapy containing highly emetogenic cisplatin based chemotherapy was administered to all the patients. For prevention of delayed chemotherapy induced nausea and vomiting all patients were prescribed oral $5-\mathrm{HT}_{3}$ antagonists. Oral Ondansetron $4 \mathrm{mg}$ TDS was given to cohort 1; Oral Granisetron $1 \mathrm{mg}$ BD given to cohort 2; and oral Palonosetron $0.5 \mathrm{mg}$ OD to the cohort 3 from day 3 to day 7 . The patients were asked to keep a vomiting diary, were interviewed on telephone and on next follow up visit and then results were graded according to the response obtained by each individual.

\section{Evaluation criteria}

The CR (complete response) to delayed vomiting was defined as no occurrence of vomiting at all times post chemotherapy without usage of salvage medications. ${ }^{5}$

Statistical analysis was done with SPSS v20 and data was analysed in Microsoft excel sheet.

\section{RESULTS}

A total of 75 patients of squamous cell carcinoma of head and neck $(\mathrm{H} \& \mathrm{~N})$, receiving highly emetogenic chemotherapy were enrolled. Of these, 47 were males and 28 were females $(\mathrm{M}: \mathrm{F}=1.67: 1)$. The mean age of patients was 47 years. Of all the cases, 25 patients received oral Ondansetron $4 \mathrm{mg}$ TDS (cohort-1), 25 patients received oral Granisetron $1 \mathrm{mg}$ BD (cohort-2) and 25 patients received oral Palonosetron $0.5 \mathrm{mg}$ OD (cohort-3) from day 3 to day 7 for prevention of delayed CINV.

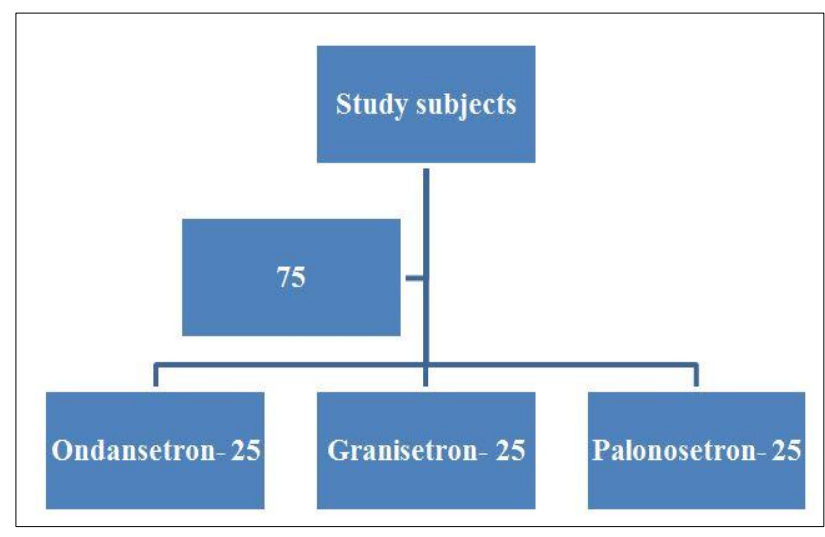

Figure 1: Flow chart showing distribution of patients in each arm.

The results were analysed on the basis of response obtained from the study subjects. They were graded as complete response when they did not have complaint of nausea and vomiting.

In Ondansetron cohort on an average $29 \%$ patients, in Granisetron cohort on an average $53 \%$ patients and in Palonosetron cohort on an average $98 \%$ patient had complete response (Figure 2). 


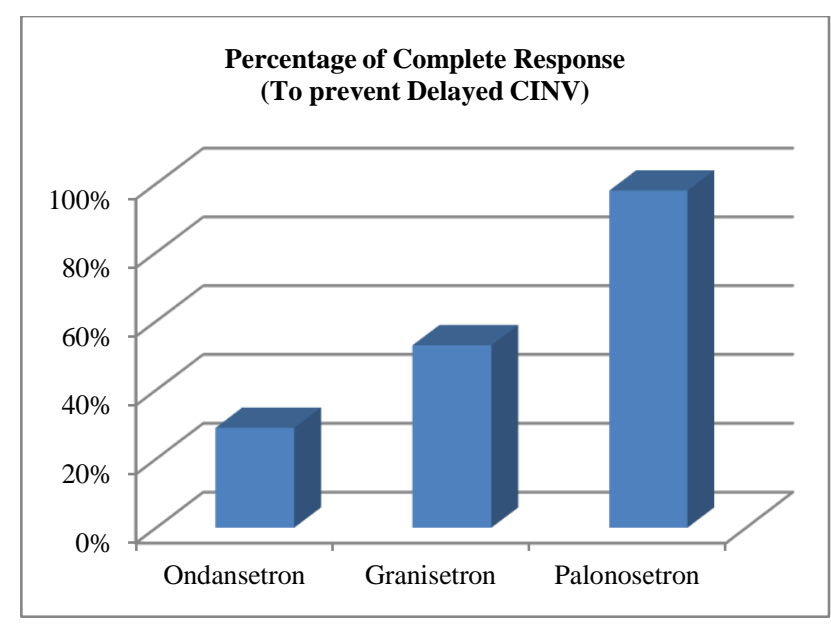

Figure 2: Percentage of patients showing CR with oral 5-HT3 antagonists.

Thus, as compared to other 5-HT3 receptor antagonists, Palonosetron had better response in prevention of delayed chemotherapy induced nausea and vomiting.

\section{DISCUSSION}

Vomiting is triggered when afferent impulses from the cerebral cortex, chemoreceptor trigger zone (CTZ), pharynx, and vagal afferent fibers of the gastrointestinal tract travel to the vomiting center, which is located in the medulla. Efferent impulses then travel from the vomiting center to the abdominal muscles, salivation center, cranial nerves, and respiratory center, thereby causing vomiting. ${ }^{6}$ The main neurotransmitter receptors involved in this signalling are serotonin (specifically 5-HT3), neurokinin1 (NK-1), and dopamine receptors. During chemotherapy, serotonin is released and activates the 5-HT3 receptors which are present predominantly on the peripheral terminals of vagal afferents in the gastrointestinal tract and in CTZ that lies in the area postrema outside of the blood-brain barrier. The CTZ signals to another area, the nucleus tractus solitarius, in the brain stem that also receives emetogenic stimuli from higher brain centers (e.g., cortical and vestibular) as well as gastrointestinal tract. $^{2}$

Agents with the highest emetogenic potential which result in emesis during the first 24 hours post-chemotherapy (acute CINV) include cisplatin, high dose cyclophosphamide, carmustine, dacarbazine and mechlorethamine. ${ }^{5,6}$ Risk factors for CINV include the emetogenic potential of the specific drug, the dose used, the treatment schedule, and how chemotherapy agents are combined. Patient characteristics that increase the risk of CINV include female gender, younger age, previous exposure to chemotherapy, history of alcohol abstention, and presence of nausea and vomiting with prior chemotherapy. ${ }^{6}$ Because 5-HT3 receptors are important neurotransmitters involved in CINV, drugs that inhibit these receptors are commonly used in clinical practice.
Among the various types of available anti-emetic agents, 5-HT3 receptor antagonists have become established as the cornerstone of therapy for prevention of CINV, due to their proven efficacy and low incidence of side effects.

First-generation 5-HT3 receptor antagonists (ondansetron, granisetron, dolasetron, and tropisetron) possess an equivalent safety and efficacy profile when used at equipotent doses. ${ }^{6-8}$ Palonosetron is a highly selective 5HT3 receptor antagonist that exhibits high 5-HT3 receptor affinity. It differs from other drugs in this class in that the plasma half-life ( 40 hours) is substantially longer and it exhibits allosteric binding and positive co-operativity. Furthermore, binding of palonosetron to 5-HT3 receptors seems to induce internalization of receptors, thereby, facilitating long-lasting receptor inhibition and activity.

The current study provides evidence that Palonosetron given to patients receiving highly emetogenic chemotherapy has clinical and statistical superiority in preventing chemotherapy induced nausea and vomiting as compared to ondansetron and granisetron. In our study, Palonosetron was given in a dose of $0.5 \mathrm{mg}$ OD which was found to be more affective as compared to ondansetron $4 \mathrm{mg}$ thrice a day and granisetron $1 \mathrm{mg}$ twice a day.

In this study, only $29 \%$ patients in ondansetron cohort showed complete response as compared to $98 \%$ patients in palonosetron cohort. This was consistent with the study done by Aapro et al, and Gralla et al.,9

Also, 53\% patients in granisetron cohort had complete response as compared to $98 \%$ patients in palonosetron cohort. This was consistent with the study done by Rhulmann and Herrstedt, and Saito et al. ${ }^{4,10}$

A meta-analysis by Celio et al found palonosetron to be statistically superior to other $5-\mathrm{HT}_{3}$ receptor antagonists during the delayed phase of nausea \& vomiting. ${ }^{11}$ Even though previous studies have shown that all 5-HT3 receptor antagonists are equally effective and safe for the prevention of acute CINV for chemotherapy regimens, NCCN (National Comprehensive Cancer Network) updated its practice guidelines by listing palonosetron as the "preferred" 5-HT3 receptor antagonist for the prevention of CINV associated with HEC. ${ }^{12}$ Another valuable study stated that, in comparison to a first generation 5-HT3 receptor antagonist palonosetron demonstrated efficacy in the prevention of delayed CINV associated with HEC. ${ }^{1}$

\section{CONCLUSION}

Cisplatin based combination chemotherapy, used in the study are highly emetogenic chemotherapeautic agents (HEC). Poor control of acute CINV (chemotherapy induced nausea and vomiting) is an established predictor for delayed CINV that typically peaks in severity between day 2 and day 4 post-chemotherapy. Thus, this study was 
conducted to compare the efficacy of 5-HT3 receptor antagonists in preventing delayed CINV and it showed palonosetron $(98 \% \mathrm{CR})$ to be far more effective than ondansetron $(29 \% \mathrm{CR})$ and granisetron $(53 \% \mathrm{CR})$. As our study was conducted in only a handful of patients and compared palonosetron against only two 5-HT3 receptor antagonists, so a larger study including various 5-HT3 receptor antagonists is suggested to establish the efficacy and better response of palonosetron.

Funding: No funding sources Conflict of interest: None declared

Ethical approval: The study was approved by the Institutional Ethics Committee

\section{REFERENCES}

1. Kim KI, Lee DE, Cho I, Yoon JH, Yoon SS, Lee HS, et al. Effectiveness of Palonosetron Versus Other Serotonin 5-HT3 Receptor Antagonists in Triple Antiemetic Regimens During Multiday Highly Emetogenic Chemotherapy. Ann Pharmacotherap. 2012;46:1637-44.

2. Vicky TC, Yeo CW. Antiemetic therapy options for chemotherapy induced nausea and vomiting in breast cancer patients. Breast Cancer: Targets Therap. 2011;3:151-60.

3. Eisenberg P, Figueroa-Vadillo J, Zamora R, Charu V, Hajdenberg J, Cartmell A, et al. Improved Prevention of Moderately Emetogenic Chemotherapy-Induced Nausea and Vomiting with Palonosetron, a Pharmacologically Novel 5-HT3 Receptor Antagonist, Results of a Phase III, Single-Dose Trial Versus Dolasetron. Cancer. 2003;98(11):2473-82.

4. Ruhlmann C, Herrstedt J. Palonosetron hydrochloride for the prevention of chemotherapy-induced nausea and vomiting, Expert Rev Anticancer Ther. 2010;10(2):137-48.

5. Liu L, Guo J, Fang S, Han X, Xie C, Liu J, et al. Therapeutic effects of palonosetron plus tropisetron on chemotherapy-induced nausea and vomiting. Int $\mathbf{J}$ Clin Exp Med. 2018;11(4):4108-13.

6. Aapro MS, Grunberg SM, Manikhas GM, Olivares G, Suarez T, Tjulandin SA, et al. A phase III, doubleblind, randomized trial of palonosetron compared with ondansetron in preventing chemotherapy- induced nausea and vomiting following highly emetogenic chemotherapy. Ann Oncol. 2006;17(9):1441-9.

7. Jordan K, Hinke A, Grothey A. Ameta-analysis comparing the efficacy of four 5-HT3 receptor antagonists for acute chemotherapy induced emesis. Support Care Cancer. 2007;15:1023-33.

8. Billio A, Morello E, Clarke MJ. Serotonin receptor antagonists for highly emetogenic chemotherapy in adults. Cochrane Database Syst Rev. 2010;2010:CD006272.

9. Gralla R, Lichinitser M, Van Der Vegt S, Sleeboom H, Mezger J, Peschel C, et al. Palonosetron improves prevention of chemotherapy-induced nausea and vomiting following moderately emetogenic chemotherapy: results of a double-blind randomized phase III trial comparing single doses of palonosetron with ondansetron. Ann Oncol. 2003;14(10):1570-7.

10. Saito M, Aogi K, Sekine I, Yoshizawa H, Yanagita Y, Sakai H, et al. Palonosetron plus dexamethasone versus granisetron plus dexamethasone for prevention of nausea and vomiting during chemotherapy: a double-blind, double-dummy, randomised, comparative phase III trial. Lancet Oncol. 2009;10(2):115-24.

11. Celio L, Niger M, Ricchini F, Agustoni F. Palonosetron in the prevention of chemotherapyinduced nausea and vomiting: an evidence-based review of safety, efficacy, and place in therapy. Core Evid. 2015;10:75-87.

12. Gralla RJ, Navari RM, Hesketh PJ, Popovic W, Strupp J, Noy J, et al. Single-dose oral granisetron has equivalent antiemetic efficacy to intravenous ondansetron for highly emetogenic cisplatin-based chemotherapy. J Clin Oncol. 1998;16:1568-73.

Cite this article as: Khare A, Mandloi V, Shrivastava A, Shrivastava AK, Wadagbalkar P, Kumar A. Impact of oral palonosetron in improving quality of life as compared to other oral 5-HT3 antagonists in delayed chemotherapy induced nausea and vomiting in patients of head and neck cancer. Int J Basic Clin Pharmacol 2019;8:493-6. 